Article

\title{
The Effect of Analyst Coverage on the Relationship between Seasoned Equity Offerings and Investment Efficiency From Korea
}

\author{
Hyun Min Oh ${ }^{1}$ and Woo young $\mathrm{Kim}^{2, *}$ \\ 1 School of Business, Hanyang University, 222 Wangsimni-ro, Seongdong-gu, Seoul 04763, Korea; \\ gusals@hanyang.ac.kr \\ 2 College of Social Science, Dongduk Women's University, 60, Hwarang-ro 13-gil, Seongbuk-gu, \\ Seoul 02748, Korea \\ * Correspondence: Kimwy01@dongduk.ac.kr; Tel.: +82-10-5410-2547
}

Received: 16 June 2018; Accepted: 30 July 2018; Published: 1 August 2018

\begin{abstract}
In order for a firm to remain sustainable, it must establish a strategy that is appropriate to its changing environment. One of these strategies is that the procurement of capital and the efficient operation of the procured capital are directly linked to the sustainability of the firm. This study empirically analyzes the relationship between seasoned equity offerings (hereafter SEO) and investment efficiency. We examine the investment efficiency of firms that have SEO and those that do not, and then analyze the effect of analysts on the relationship between SEO and investment efficiency. The empirical results of this study are as follows. First, there is a significant negative correlation between SEO and investment efficiency, meaning that firms with SEO have lower investment efficiency than firms without SEO. Second, the interaction variable between SEO and analyst participation showed a significant positive correlation with investment efficiency, meaning that the more active the analyst, the more any ineffective investment that is derived from managers' opportunistic earnings management is suppressed. The results show that the efficient operation of procured capital is important for the sustainability of the firm, and that the analyst plays an important role in monitoring the efficient allocation of resources as an external auditor.
\end{abstract}

Keywords: seasoned equity offerings; sustainable strategy; investment efficiency; analyst coverage; analyst followings

\section{Introduction}

In order for a firm to remain sustainable, it must respond appropriately to its environment. The environment is not static, but rather changes from time to time. In order to cope with a changing environment and sustain the firm, it is important to finance and operate capital well. This study examines the sustainability of firms from the viewpoint of capital procurement and operation. Firms seek to maximize their value by obtaining financing for management activities and operating them efficiently. Financing is obtained by borrowing through banks, issuing bonds, or seasoned equity offerings (SEO). In this study, we examine financing through SEO.

The purposes of SEO are usually facility and operation financing, debt repayment, and the improvement of financial conditions. SEO is an important factor in determining a firm's value because it is linked to investment as well as financing [1]. In the case of a firm with SEO, an increase in the issuance price of a new stock increases existing shareholders' wealth. Therefore, management has an incentive to raise earnings so as to brighten the future of the firm [2]. Firms that plan to capitalize on stocks want to sell their stocks to investors at the highest possible price, so there is an incentive to overestimate the net earnings, using accruals to attract investors [3]. 
If there is an imbalance in information between the management and the new investors in SEO, management will be tempted to employ opportunistic earnings strategies to protect the wealth of existing shareholders. In other words, if the firm adopts new fund-raising methods through SEO rather than debt financing, the incentive of earnings management will be high. In the case of a firm that conducts SEO, the manager manages the earnings through accruals [4-7] and real activities [8,9].

Several studies have analyzed equity and debt cost savings $[10,11]$ in terms of financing, and Bharath et al. (2008) [12] analyzed the impact of debt market conditions on access to debt markets, lower borrowing costs for bank borrowing, longer debt maturity conditions, and lower guarantee conditions. Hong and Lee (2016) [13] compared discretionary accruals before financing according to firms with SEO and bond issuance. They showed that firms with SEO manage upward earnings more efficiently than firms with bond issuance. In addition, Ban (2011) [14] found that the benefits of accounting information on investment decisions are greater for financing firms through stock trading than for issuing bonds and bank financing. Bushman and Smith (2001) [15] argued that accounting information directly or indirectly influences firm value by inducing effective investment choices and enhancing information transfer and market surveillance by aggregating capital market information. Ashbaugh et al. 2006 [16] suggested that high-quality accounting information effectively mitigates managerial opportunistic behavior by reducing information asymmetry among stakeholders and enhancing supervision and oversight of managers. Ban (2011) [14] reported that the quality of accounting information is negatively correlated with the agent problem, and positively correlated with investment efficiency. Son (2013) [17] reported that when a firm with a large discretionary accrual incurred resource allocation errors for fixed assets, the investment efficiency decreased. Overall, if the quality of earnings is low, investment efficiency is low [18-21]. Thus, since the study of Biddle and Hilary (2006) [18], the research on investment efficiency has mainly been focused on the quality of earnings.

This study examines whether the investment efficiency is lowered due to SEO if SEO are accompanied by earnings management and accounting quality is lowered. There is little research on the relationship between SEO and investment efficiency, which is the starting point of investment. In this paper, we propose that the relationship between financing through SEO and accounting information is greater than debt financing, and we examine the relationship between SEO and investment efficiency. If a firm chooses an investment plan with a positive net present value (NPV) when there is no agency cost or reverse selection problem corresponding to market friction, then over or underinvestment does not occur. In other words, it was defined that investment was efficient in an optimal state [19].

The analyst plays the role of the intermediary, collecting information and analyzing the information about the firm for information users. Analysts as information intermediaries indirectly monitor management activities through the verification of accounting information. Analysts have a high level of expertise in analyzing financial statements and industry-wide knowledge to effectively review firms' financial reporting [22]. It has recently been reported that analysts play a role in monitoring managerial accounting choices, in addition to their role as information intermediaries. Yu (2008) [23] and Knyazeva (2007) [24] reported that there is a negative correlation between the number of analysts and the earnings management level. This implies that the analyst performs an important monitoring role in the management's financial reporting activities. Choi and Lee (2015) [25] reported that analysts induce efficient investment by examining the positive association between analysts and investment efficiency.

Based on these prior studies, we analyze whether the analysts operate as a mechanism to control the negative relationship between SEO and investment efficiency. It is anticipated that earnings management in the case of SEO will reduce investment efficiency in the future, and that analysts' motivation to enhance investment efficiency will be lowered due to SEO, because it plays a role in constraining earnings management. McNichols and Stubben (2008) [21] used proxy as a proxy for investment efficiency. 
The empirical results are as follows. First, there is a significant negative relationship between SEO and investment efficiency. This implies that a firm with SEO is less efficient than a firm without SEO. As in the prior research, it is interpreted that SEO accompany earnings management, and this earnings management causes the resource allocation error of the fixed assets to have lower investment efficiency. Second, the interaction variable between SEO and the number of analysts showed a significant positive relationship with investment efficiency. This implies that the higher the monitoring effect of the analyst, the more the ineffective investment derived from the managements' opportunistic earnings management is suppressed. Analysts' coverage improves the investment efficiency of a firm by indirectly monitoring the firm's management.

The contributions are as follows. First, as in prior studies, if earnings on SEO are managed, then the empirical analysis shows that investment efficiency can fall after earnings management. It is believed that this provides additional empirical evidence for a prior study $[5,6,8,9]$ that predicts poor earnings results due to the reversal of earnings management and real activities with SEO. Second, it is shown that analysts can monitor the quality of financial reporting by showing that analyst coverage positively improves the relationship between SEO and investment efficiency. This implies that the greater the analyst coverage, the more likely it is that earnings management will be constrained in the case of SEO, reducing the size of the reversal of accruals and efficiency, and efficiently allocating the funds to fixed assets.

The rest of the paper is as follows. Section 2 follows the introduction, Section 2 presents the theoretical background and hypothesis setting, and Section 3 describes the research design. In Section 4, we present the results of empirical analysis, and in Section 5, we present the results of the study.

\section{Prior Literature and Hypothesis}

\subsection{SEO and Earnings Management}

The study of Rangan (1998) [5] and Teoh et al. 1998 [6] led to the interest in managing the reported earnings for SEO and the response of accounting figures and stock market responses related to such earnings management. The research on earnings management is mainly focused on the earnings management through accruals. However, recently, the research on earnings management through real activities has been carried out.

The study of accrued earnings management related to SEO is based on the empirical result that low stock returns and low earnings result after SEO. Researchers have raised the earnings at the time of SEO [5,6,26]. Rangan (1998) [5] reported that, on average, a firm with SEO reduces its earnings by reporting abnormal accruals on SEO, and that this accrual predicts earnings reversal and poor earnings in the next year. The study of Teoh et al. 1998 [6] was also similar to that of Rangan (1998) [5]. They raised that the earnings on SEO lead to a low stock price return and a poor earnings report after SEO. Rangan (1998) [5] and Teoh et al. 1998 [6] explained that the reason for the decline in operating performance is because SEO are mainly due to the reversal of accruals. In Korea, Choi and Paek (1999) [4] and Yoon and Lee (2001) [7] reported that firms with SEO manage earnings through accruals. Hong and Lee (2016) [13] showed that firms with SEO had more earnings management than firms with bond issuance.

Next, we examine the study on earnings management through real activities in SEO. Cohen and Zarowin (2010) [8], as well as Kang and Jeon (2010) [9], reported that firms engage in earnings management through real activities, and that earnings after SEO due to real activities earnings management are more serious than earnings management through accruals. In other words, poor earnings after SEO reflect not only the reversal of accruals, but also the actual results of the business decisions to manage earnings. As a result of the analysis, managers use real activities in addition to accruals to increase earnings before SEO.

The results of prior studies related to the above SEO suggest that managers manage earnings through accrual and real activities before and after SEO. If the upward earnings management through 
accruals and earnings management through real activities are made at the managers' opportunistic discretion, this suggests that the manager increases the issuance price of new shares in order to protect the wealth of existing shareholders.

\subsection{Earnings Management and Investment Efficiency}

Investment efficiency refers to the adoption of investment plans with positive net present value (hereafter NPV) under circumstances where there is no market friction such as adverse selection or agency costs. In other words, investing despite overinvestment in the NPV is negative, and abandoning investment opportunities with positive NPV constitutes underinvestment $[19,27]$.

In order to maximize the firm value, it is important to make the best investment with the given capital. However, due to realistic constraints, optimal investment is often not achieved. In the neo-classical theory, it is argued that in order to maximize firm value, investment should be made until marginal revenue equals a marginal cost of investment [28-30]. On the other hand, Keynesian theory [31,32] argued that corporate investment is determined by expectations of growth or the preference of the firms' financial stability. Myers (1977) [33] reported that when there is an agent problem due to an information asymmetry problem, the optimal investment is not made, and thus there is underinvestment or overinvestment.

If capital market is perfect, investment projects with positive NPV will obviously not be the case in many studies, although it is natural that the investment will be made [34,35]. According to agent theory, overinvestment and underinvestment are explained by the problem of information asymmetry among stakeholders. Jensen and Meckling (1976) [36], Myers (1977) [33], and Myers and Majluf (1984) [37] argued that problems of information asymmetry such as moral hazard and adverse selection are related to investment efficiency. In addition, it is a moral hazard between the manager and shareholder to make an unfair earnings share to shareholders [36], because it maximizes the manager's interests by transferring the economic losses from the overinvestment to shareholders [38].

Under adverse selection, managers with better information issue stocks at high prices, and overinvest if they achieve excess returns. This adverse selection can be avoided by the supplier of capital rationally supporting capital or by increasing the cost of capital use.

However, it may not be possible to carry out a project that may generate earnings due to financing constraints such as a lack of investment in the future $[19,39,40]$.

Based on this theoretical background, studies in the accounting field have focused on the role of accounting information to complement the imperfection of capital markets such as information asymmetry and agency costs, and the discovery of mechanisms that lead to optimal investment decisions. The higher the quality of earnings, the better the manager can recognize the better project and make the right investment decision, which can lead to an improvement in the investment efficiency of the firm $[15,21]$.

McNichols and Stubben (2008) [21] also found that earnings management causes excessive investment. This explains why information distortions caused by earnings management caused excessive investment. Biddle et al. 2009 [19] analyzed the effects of overinvestment and underinvestment on the quality of earnings for United States (US) firms. Chen et al. 2011 [20] analyzed the effects of overinvestment and underinvestment on the quality of earnings for private firms in emerging markets. Similarly, Garcia-Lara et al. (2010) [41] reported that conservatism in accounting can reduce both overinvestment and underinvestment. This implies that the conservativeness of the accounting process reduces the investment cash flow of overinvested firms and facilitates the access of external funds for underinvestment firms.

In Korea, Ban (2011) [14] suggested that when credible accounting information is provided, the shareholders' monitoring role in management is strengthened, and investment decisions can be made. Son (2013) [17] analyzed the relationship between earning quality, capital investment, and investment efficiency. As a result, firms with larger discretionary accruals in the past had lower returns on future assets and lower investment efficiency. In other words, the higher the discretionary 
accruals, the less effective the allocation of resources to fixed assets. Choi and Kim (2012) [42] analyzed why the market did not recognize the large amount of discretionary accruals accrued by managerial opportunistic incentives in a timely manner. They concluded that the managerial discretionary accounting practices and the market reaction may have had an adverse effect on the future investment performance of the firm.

As we have seen above, we can conclude from the prior research results related to investment efficiency that investment is efficient when information converges to balance in the relationship between owner and agent. As part of efforts to reduce agency costs, the quality of accounting information suggests that investment efficiency can be enhanced.

\subsection{Analysts' Coverage, SEO, and Investment Efficiency}

Analysts play a key role in firm information analysis. Analysts collect not only public information, but also private information to perform forecasting activities. Analysts also play a role in mitigating information asymmetry problems arising from the separation of ownership and management. In addition, recent researchers have shown that the disclosure of information through analysts' forecast activities can improve the quality of financial reporting.

Dyck et al. (2010) [43] reported that analysts (16.9\%) are more likely to detect fraudulent cases of firms than external auditors (11.3\%). Yu (2008) [23] and Yoo et al. (2012) [44] confirmed that analysts' coverage affects earnings management through accruals, and that discretionary accruals are reduced more in firms with more analyst coverage.

Doukas et al. (2008) [45] reported that the number of analysts was positively related to external financing. Also, the number of analysts is very positively related to ratios of investment such as net assets, machinery, and equipment purchases.

Goh et al. (2012) [46] analyzed whether analysts' earnings-forecasting activities effectively monitored managers' earnings-making behavior. Choi and Lee (2015) [25] analyzed the relationship between the number of analysts and investment efficiency, and suggested that analysts may have played a role in monitoring managers.

As we have seen above, analysts are reported to play the role of information intermediaries as well as be responsible for monitoring the quality of managers' financial reporting.

\subsection{Hypothesis}

The higher the quality of accruals, the less information asymmetry and the less opportunistic behavior of managers due to the reduction of market anomalies [47]. The managers' opportunistic earnings management through accruals and real activities may have a negative impact on future management performance. Firms with SEO are more likely to have lower earnings quality due to earnings management through accruals and real activities compared to those without SEO.

On the other hand, the agent problem that arises from information asymmetry does not make for optimal investment; instead, these firms experience underinvestment or overinvestment [33]. Firms can reduce information asymmetry by improving their earnings quality [15,48]. By reducing managerial adverse selection and moral hazards, firms can have better investment opportunities, and a high quality of earnings can increase investment efficiency [18-21].

Although managers can arbitrarily manipulate earnings through accounting choices, stakeholders in capital markets tend to be fixated on reported earnings, and the quality problems of capital markets tend to be evaluated later. Such a phenomenon, regardless of the quality of earnings, depends on the level of earnings, and the external capital cost is determined in the market, which affects investment decision making and financing.

Therefore, managers tend to select aggressive accounting to increase reported earnings in the application of accounting principles and report them to the outside. However, this accounting choice and the fixed response of the market in the decision making of the investor can hinder the efficient 
allocation of the investment resources to fixed asset investment, and negatively affect the future investment performance of the firm [42].

Thus, in many prior studies, it is argued that the better the quality of earnings, the better the investment efficiency [14,18-21]. If the relationship between SEO and investment efficiency is related to the earnings management through accruals and real activities when SEO are made opportunistically $[6,8,9]$, then the earnings quality of the firm is undermined, and the damaged earnings quality will increase the information asymmetry and lead to inefficient investment $[14,17,42]$.

We hypothesize as follows:

Hypothesis $\mathbf{1}\left(\mathbf{H}_{\mathbf{1}}\right)$. Investment efficiency will be lower in firms with SEO than those without SEO.

Analysts discover and monitor managers' hidden earnings management [23,43,44]. Analysts seek to track firms' information and perform insightful analysis for in order to garner a higher reputation and earn more pay. The insightful analysis of analysts is highly likely to detect earnings management through managers' discretionary accruals or real activities by predicting correct actual performance.

Dyck et al. (2010) [43] suggested that analysts outperform the SEC (Securities and Exchange Commission) and external auditors in the detection of fraud. Sun (2009) [49], Sun and Liu (2011) [50], and $\mathrm{Yu}$ (2008) [23] reported that analysts act as observers in the financial reporting process. For example, analysts may be interested in the media when they query a firm for unexpected earnings or abnormal activities in the process of predicting a firm's earnings, or when they identify a firm's suspicious circumstances.

On the other hand, if earnings management is performed in SEO, accounting information becomes opaque. The reduction of accounting transparency ultimately increases the information asymmetry between firm and investors, and the information risk of accounting information is assumed by investors. Then, the performance of the firm is likely to decline over the long term because of the risk of such information [51].

As such, the quality of financial reporting, which has been damaged by earnings management on $\mathrm{SEO}$, can have a negative impact on investment decisions. The agent problem of investment decision is caused by information asymmetry between the manager and the shareholder. The more the monitoring by analysts is strengthened and the accounting quality is improved, the more the agent problem can be mitigated and the investment efficiency can be improved [14].

In sum, investment efficiency is expected to decrease if managers' conduct opportunistic earnings management for private benefits in cases of SEO. However, analysts perform monitoring to constrain the opportunistic earnings management of managers. As a result, managers' opportunistic earnings management will decrease, and the quality of accounting earnings will improve. Therefore, the greater the number of analysts who follow the firm, the more likely it is that the relationship between SEO and investment efficiency will be mitigated.

We hypothesize as follows:

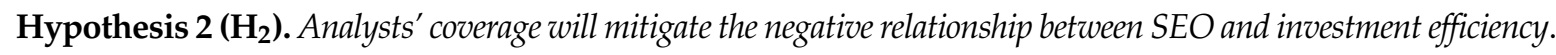

\section{Research Design}

\subsection{Regression Models}

We hypothesized that the quality of the earnings damaged by SEO would have a negative impact on the investment efficiency. The regression model for Hypothesis 1 is shown in Equation (1):

$$
\begin{aligned}
& I N V_{-} E F_{i t+1}=\beta_{0}+\beta_{1} S E O D U D M_{i t-1}+\beta_{2} E Q_{i t}+\beta_{3} S I Z E_{i t}+\beta_{4} L E V_{i t} \\
& +\beta_{5} \text { LOSSDUM }_{i t}+\beta_{6} T A_{i t}+\beta_{7} S T D_{-} O C F_{i t}+\beta_{8} A G E_{i t} \\
& +\beta_{9} S L A S C K_{i t}+\beta_{10} O W N_{i t}+\beta_{11} F O R_{i t}+\beta_{12} B I G 4_{i t} \\
& +\sum Y D+\sum I D+\varepsilon_{i t}
\end{aligned}
$$


where the dependent variable, investment efficiency, was measured by the method of McNichols and Stubben (2008) [21]. Investment efficiency means that the absolute value of the residual measured by McNichols and Stubben (2008) [21] is multiplied by -1 , and the larger the value, the greater the investment efficiency. See Appendix B.1 for the definition of investment efficiency. The SEODUM of Equation (1) is 1 for a firm with SEO, and 0 for a firm without SEO. SEODUM is the variable of interest of Hypothesis 1, and its predictive sign is negative. In other words, it is predicted that investment efficiency will be lower for firms with SEO.

Prior studies reported that analysts monitor firms to improve the quality of financial reporting. In this study, we predict that the quality of financial reporting raised by analysts will mitigate the negative relationship between SEO and investment efficiency. The regression model for Hypothesis 2 is shown in Equation (2).

In Equation (2), SEODUM $\times$ FOLLOW is the variable of interest for Hypothesis 2, and its predictive sign has a positive direction. Thus, the higher the analyst coverage, the more likely it will work as a mechanism to mitigate the negative relationship between SEO and investment efficiency.

$$
\begin{aligned}
I N V_{-} E F_{i t+1}= & \beta_{0}+\beta_{1} \text { SEODUM }_{i t-1}+\beta_{2} \text { FOLLOW }_{i t}+\beta_{3} \text { FOLLOW }_{i t} \times \text { SEODUM }_{i t-1} \\
& +\beta_{4} E Q_{i t}+\beta_{5} \text { SIZE }_{i t}+\beta_{6} L E V_{i t}+\beta_{7} \text { LOSSDUM }_{i t}+\beta_{8} T A_{i t} \\
& +\beta_{9} S T D \_O C F_{i t}+\beta_{10} A G E_{i t}+\beta_{11} S L A S C K_{i t}+\beta_{12} \text { OWN }_{i t} \\
& +\beta_{13} \text { FOR }_{i t}+\beta_{14} \text { BIG }_{i t}+\sum Y D+\sum I D+\varepsilon_{i t}
\end{aligned}
$$

where the control variables are defined as follows. $E Q$ is a variable representing the quality of earnings. SIZE is the size of the firm. LEV is the debt ratio of a firm. LOSSDUM is the loss dummy variable. $T A$ is the tangible asset ratio. STD_OCF is the standard deviation of operating cash flows for five years from period $t-4$ to period $t$. AGE is the listing period of the firm. SLACK is the ratio of cash divided by total assets, OWN is the ratio of the largest shareholder's ownership, and FOR is the ratio of foreign ownership. BIG4 is a BIG4 auditor dummy variable. See Appendix A for the detailed description of variables.

Control variables were selected by referring to prior studies $[18,20,52]$. Earnings quality $(E Q)$ is included in control variables according to the results of prior studies that have a positive relationship with investment efficiency and added to control investment efficiency according to firm size (SIZE) and debt ratio $(L E V)$. In addition, they are included in control variables, taking into account the impact of LOSSDUM, volatility of operating cash flow (STD_OCF), and firm age (AGE) on investment efficiency [19]. SLACK is included in order to control the funding capacity of capital investment, and tangible asset ratio (TA) is also included in order to control the impact of past capital investment levels [19,52]. Additionally, in order to control for the effect of corporate governance on investment efficiency, the largest shareholders ownership $(O W N)$ and foreign ownership $(F O R)$ were selected as control variables.

\subsection{Sample Selection}

We use the data collected from firms listed on the Korea Stock Exchange and select firms that meet the following conditions as a sample. We used 31 December firms and non-financial firms for fiscal years and firms. We used firms that had financial data and stock price information in the FN Data Guide provided by the Financial Information and Solution Co., Ltd. (Seoul, Korea). Also, we used firms that had SEO data from KIS-VALUE provided by NICE Information Service Co., Ltd. (Seoul, Korea). The analysis period is from 2002 to 2014.

Table 1 shows the sample selection process. First, financial firms and non-December firms are excluded. Second, firms without financial and stock data are excluded. The final sample used in the analysis consisted of 5297 firms. In order to minimize the impact of outliers on the analysis results, we use Winsorized at the $1 \%$ level for continuous variables, except for the dummy variables. 
Panel A of Table 2 shows the distribution of the sample by year. The sample size was similar for each year, and for the whole period, $12 \%$ of the total sample size was for SEO. Panel B of Table 2 shows the distribution of the sample by industry. Medical manufacturing (17.02\%), PC (Personal Computer), and the medical industry $(16.62 \%)$ showed a lot of SEO. On the other hand, fiber, clothes and leathers, $(4.51 \%)$ and the rubber and plastics industry $(6.57 \%)$ showed less SEO.

Table 1. Sample Selection.

\begin{tabular}{cc}
\hline Sample Selection Criteria & Firm-Year Observations \\
\hline Firms listed in the Korea Stock Exchange, 2002 to 2014 & 7883 \\
(less) Firms with fiscal year end except December and financial firms & $(622)$ \\
(less) Financial and stock data could not be collected from the FN Data Guide & $(1964)$ \\
Final sample & 5297 \\
\hline
\end{tabular}

Table 2. Distributions over the Sample Period. SEO: seasoned equity offerings.

\begin{tabular}{|c|c|c|c|c|c|}
\hline \multicolumn{6}{|c|}{ Panel A: Distribution across Fiscal Years } \\
\hline Year & Subtotal & $\begin{array}{l}\text { The Number of a } \\
\text { Firm with SEO }\end{array}$ & Percent (\%) & $\begin{array}{l}\text { The Number of a } \\
\text { Firm without SEO }\end{array}$ & Percent (\%) \\
\hline 2002 & 343 & 46 & 13.41 & 297 & 86.59 \\
\hline 2003 & 358 & 32 & 8.94 & 326 & 91.06 \\
\hline 2004 & 383 & 32 & 8.36 & 351 & 91.64 \\
\hline 2005 & 387 & 33 & 8.53 & 354 & 91.47 \\
\hline 2006 & 407 & 40 & 9.83 & 367 & 90.17 \\
\hline 2007 & 375 & 54 & 14.4 & 321 & 85.60 \\
\hline 2008 & 371 & 56 & 15.09 & 315 & 84.91 \\
\hline 2009 & 403 & 39 & 9.68 & 364 & 90.32 \\
\hline 2010 & 417 & 65 & 15.59 & 352 & 84.41 \\
\hline 2011 & 436 & 58 & 13.30 & 378 & 86.70 \\
\hline 2012 & 459 & 67 & 14.60 & 392 & 85.40 \\
\hline 2013 & 480 & 71 & 14.79 & 409 & 85.21 \\
\hline 2014 & 478 & 63 & 13.18 & 415 & 86.62 \\
\hline Total & 5297 & 656 & 12.38 & 4641 & 8762 \\
\hline \multicolumn{6}{|c|}{ Panel B: Industry Distribution } \\
\hline Industry & Subtotal & $\begin{array}{l}\text { The Number of a } \\
\text { Firm with SEO }\end{array}$ & Percent (\%) & $\begin{array}{l}\text { The Number of a } \\
\text { Firm without SEO }\end{array}$ & Percent (\%) \\
\hline Food, Beverage & 347 & 37 & 10.66 & 310 & 89.34 \\
\hline Fiber, Clothes, Leathers & 266 & 12 & 4.51 & 254 & 95.49 \\
\hline Timber, Pulp, Furniture & 277 & 31 & 11.19 & 246 & 88.81 \\
\hline Cokes, Chemical & 699 & 69 & 9.87 & 630 & 90.13 \\
\hline Medical Manufacturing & 282 & 48 & 17.02 & 234 & 82.98 \\
\hline Rubber and Plastic & 198 & 13 & 6.57 & 185 & 93.43 \\
\hline Non-Metallic & 231 & 22 & 9.52 & 209 & 90.48 \\
\hline Metallic & 513 & 55 & 10.72 & 458 & 89.28 \\
\hline PC, Medical & 391 & 65 & 16.62 & 326 & 83.38 \\
\hline Machine and Electronic & 412 & 54 & 13.11 & 358 & 86.89 \\
\hline Other Transportation & 450 & 74 & 16.44 & 376 & 83.56 \\
\hline Construction & 167 & 21 & 12.57 & 146 & 87.43 \\
\hline Retail and Whole Sales & 246 & 39 & 15.85 & 207 & 84.15 \\
\hline Transportation Service & 217 & 22 & 10.14 & 195 & 89.86 \\
\hline Publishing, Broadcasting & 53 & 6 & 11.32 & 47 & 88.68 \\
\hline Professional Services & 239 & 38 & 15.90 & 201 & 84.10 \\
\hline Other & 309 & 50 & 16.18 & 259 & 83.82 \\
\hline Total & 5297 & 656 & 12.38 & 4641 & 8762 \\
\hline
\end{tabular}




\section{Empirical Results}

\subsection{Descriptive Statistics}

Panel A of Table 3 is the descriptive statistics of the main variables. The mean (median) of investment efficiency (INV_EF) is $-0.079(-0.040)$, and 0.124 on the firm with SEO (SEODUM). The mean (median) of firm size (SIZE) is 26.547 (26.261), and the mean (median) of debt ratio (LEV) is $0.483(0.472)$. The ratio of firms with negative earnings (LOSSDUM) is about $20 \%$. The tangible asset ratio (TA) is about $38 \%$, and the cash ratio (SLACK) is $5 \%$. The average age of the firm (AGE) is 2.773 , the largest shareholders ownership (OWN) is $42.20 \%$, and foreign ownership $(F O R)$ is $10 \%$ on average. Furthermore, $68 \%$ of auditors were audited by a BIG4 accounting firm, and the average number of analysts was 6.6 .

Table 3. Descriptive Statistics $(N=5297)$.

\begin{tabular}{cccccccc}
\hline Variable & Mean & Standard Deviation & Min & 25th Percentile & Median & 75th Percentile & Max \\
\hline INV_EF & -0.079 & 0.095 & -0.349 & -0.090 & -0.040 & -0.017 & 0.000 \\
SEODUM & 0.124 & 0.323 & 0.000 & 0.000 & 0.000 & 0.000 & 1.000 \\
FOLLOW & 6.633 & 6.292 & 1.000 & 1.000 & 4.000 & 11.000 & 30.000 \\
EQ & -0.052 & 0.055 & -0.305 & -0.069 & -0.035 & -0.015 & 0.000 \\
SIZE & 26.547 & 1.490 & 23.781 & 25.490 & 26.261 & 27.291 & 30.783 \\
LEV & 0.483 & 0.235 & 0.014 & 0.312 & 0.472 & 0.622 & 2.595 \\
LOSSDUM & 0.202 & 0.401 & 0.000 & 0.000 & 0.000 & 0.000 & 1.000 \\
TA & 0.379 & 0.202 & 0.000 & 0.237 & 0.363 & 0.495 & 2.034 \\
STD_OCF & 0.117 & 0.072 & 0.018 & 0.066 & 0.099 & 0.146 & 0.444 \\
AGE & 2.773 & 0.754 & 0.693 & 2.398 & 2.944 & 3.367 & 4.060 \\
SLACK & 0.050 & 0.056 & 0.000 & 0.012 & 0.033 & 0.069 & 0.604 \\
OWN & 0.422 & 0.161 & 0.075 & 0.310 & 0.421 & 0.531 & 0.818 \\
FOR & 0.101 & 0.145 & 0.000 & 0.004 & 0.032 & 0.142 & 0.637 \\
\hline
\end{tabular}

Notes: See Appendix A for the definition of variables.

\subsection{Correlation Analysis}

Table 4 shows the Pearson correlation analysis of the main variables. The SEO dummy variable (SEODUM), standard deviation of operating cash flow (STD_OCF), cash-holding ratio (SLACK), and foreign ownership (FOR) show a significant negative correlated with investment efficiency $\left(I N V_{-} E F\right)$. The higher the standard deviation of operating cash flow, the higher the cash-holding ratio, the higher the foreign ownership; the higher the audit result of BIG4 accounting firms, the lower the investment efficiency.

The relationship between interest variable, SEODUM, and dependent variable, $I N V_{-} E F$, is -0.060 , which means that firms with SEO have lower investment efficiency than those without SEO. Although other characteristics that affect investment efficiency are uncontrolled results, it can be seen that a firm with SEO would have a lower investment efficiency than a firm without SEO.

On the other hand, earnings quality (EQ), firm size (SIZE), debt ratio (LEV), the ratio of tangible assets (TA), and firm age ( $A G E$ ) all show a significant positive correlated with investment efficiency (INV_EF). The higher the quality of earnings, the larger the firm, the higher the debt ratio, the higher the tangible asset ratio, the longer the firm age, and the higher investment efficiency. The relationship between the quality of earnings $(E Q)$ and investment efficiency $\left(I N V_{-} E F\right)$ was 0.107 , indicating that the higher the quality of accounting information, the higher investment efficiency [28]. The relationship between size (SIZE) and investment efficiency (INV_EF) is 0.041, meaning that the larger the size of the firm, the more information is abundant in the environment and the higher the investment efficiency. The relationship between AGE and investment efficiency is 0.022. The longer the age of the firm, the more information is released into the market, and the more saturated the information environment, the higher the investment efficiency. The relationship between the largest shareholders ownership $(O W N)$ and investment efficiency is 0.045 , which shows that the higher the corporate governance structure, the higher the investment efficiency. 
Table 4. Pearson Correlations $(N=5297)$.

\begin{tabular}{|c|c|c|c|c|c|c|c|c|c|c|c|c|c|}
\hline & (2) & (3) & (4) & (5) & (6) & (7) & (8) & (9) & (10) & (11) & (12) & (13) & (14) \\
\hline (1) INV_EF & $-0.056^{* * *}$ & -0.002 & $0.104^{* * *}$ & $0.033 * *$ & $0.036^{* * *}$ & -0.005 & $0.228 * * *$ & $-0.078^{* * *}$ & $0.056^{* * *}$ & $-0.079 * * *$ & $0.040^{* * *}$ & -0.028 ** & $-0.042 * * *$ \\
\hline (2) SEODUM & & $0.094^{* * * *}$ & $-0.035^{* *}$ & -0.024 * & $0.081^{* * *}$ & $0.102^{* * * *}$ & -0.025 * & $0.086^{* * *}$ & 0.001 & 0.018 & $-0.122 * * *$ & -0.003 & $0.037^{* * *}$ \\
\hline (3) FOLLOW & & & 0.041 * & $0.593 * * *$ & $0.057 * *$ & $-0.101^{* * *}$ & $0.056^{* *}$ & 0.014 & 0.025 & -0.014 & $-0.302^{* * *}$ & $0.469^{* * * *}$ & $0.231^{* * *}$ \\
\hline (4) $E Q$ & & & & $0.146^{* * *}$ & $-0.148^{* * * *}$ & $-0.113 * * *$ & $0.112 * * *$ & $-0.262 * * *$ & $0.047^{* * *}$ & $-0.073^{* * *}$ & 0.022 & $0.070^{* * *}$ & $0.056 * * *$ \\
\hline (5) SIZE & & & & & $0.181^{* * *}$ & $-0.104^{* * *}$ & $0.123 * * *$ & $-0.137^{* * *}$ & $0.083^{* * *}$ & $-0.050 * * *$ & $-0.116^{* * *}$ & $0.503 * * *$ & $0.367^{* * *}$ \\
\hline (6) $L E V$ & & & & & & $0.184^{* * *}$ & $0.304 * * *$ & $0.134^{* * *}$ & -0.018 & $-0.138^{* * *}$ & $-0.075^{* * * *}$ & $-0.107^{* * *}$ & $0.045^{* * *}$ \\
\hline (7) LOSSDUM & & & & & & & 0.031 ** & $0.096^{* * *}$ & $0.070^{* * *}$ & $-0.083 * * *$ & $-0.091^{* * * *}$ & $-0.143^{* * * *}$ & -0.042 *** \\
\hline (8) $\mathrm{TA}$ & & & & & & & & $-0.084^{* * *}$ & $0.073^{* * *}$ & $-0.227^{* * *}$ & $0.051^{* * *}$ & $-0.045^{* * *}$ & -0.017 \\
\hline (9) STD_OCF & & & & & & & & & $-0.140 * * *$ & $0.095^{* * *}$ & 0.001 & $-0.080 * * *$ & $-0.072^{* * *}$ \\
\hline (10) $\overline{A G E}$ & & & & & & & & & & $-0.078^{* * *}$ & $-0.123 * * *$ & 0.009 & -0.031 ** \\
\hline (11) $S L A C K$ & & & & & & & & & & & $-0.040 * * *$ & $0.134^{* * *}$ & $0.040^{* * *}$ \\
\hline (12) OWN & & & & & & & & & & & & $-0.137^{* * *}$ & -0.012 \\
\hline (13) FOR & & & & & & & & & & & & & $0.258^{* * *}$ \\
\hline (14) BIG4 & & & & & & & & & & & & & \\
\hline
\end{tabular}

Note: Please refer to Appendix A for variable definitions. ${ }^{* * *}, * * * *$ denote significance at the $1 \%, 5 \%$, and $10 \%$ levels, respectively (two-tailed). 


\subsection{Multivariate Results}

Table 5 shows the regression analysis of Hypothesis 1, which examines the relationship between SEO and investment efficiency. In this study, cross-sectional regression analysis was used. In the prior research, the information asymmetry caused the difference between the optimal investment level and the possibility of overinvestment or underinvestment. Among the causes of information asymmetry, moral hazard is the act of choosing an investment plan that can yield high earnings, even if the probability of earnings generation is low. This study also examined the relationship between SEO and investment efficiency by dividing it into a total sample, an overinvestment sample, and an underinvestment sample, as in the prior studies [17,19].

The convergence of the residuals measured by the method of McNichols and Stubben (2008) [21] means that investment is efficient. If the residual is greater than 0 , it means overinvestment, and if the residual is less than 0 , it means underinvestment. In this study, we conducted a meaningful analysis of whether overinvested or underinvested funds are raised by SEO. As a result of verifying the fit of the research model, the F value is significant at the $1 \%$ level, so the research model to verify the hypothesis is not problematic.

In Table 5, the SEODUM regression coefficient $\left(\beta_{1}\right)$ showing the effect of SEO on investment efficiency was -0.045 for the full sample, which was a significant negative value at the $1 \%$ level. For the underinvestment sample, the effect of SEO on investment efficiency was -0.065 , which is a significant negative value at the $1 \%$ level. In other words, the empirical results show that firms with SEO have a lower investment efficiency than those without SEO. These results show that in the case of a SEO, the quality of earnings is deteriorated due to opportunistic earnings management, and the quality of the earnings thus damaged leads to an increase of information asymmetry. This is supported by Hypothesis 1: if unreliable accounting information is provided, the shareholders' ability to monitor the management is weakened, and inefficient investment decisions can be made [4-9].

This means that individual firms are not making optimal investment decisions after SEO, suggesting that investment is inefficient compared with firms that do not issue SEO. In addition, the statistical significance is shown only in the total sample and the underinvestment sample, suggesting that the relationship between SEO and investment efficiency may be the result of the underinvestment sample. Thus, it can be interpreted that the funds raised through SEO are not used enough for investment, resulting in an inefficiency of investment.

In terms of control variables, $E Q, S I Z E$, and the tangible asset ratio $(T A)$ were significantly positive. In the case of $E Q$, as in prior studies, investment efficiency is positive, and the higher the earnings quality, the higher the investment efficiency. In the case of firm size (SIZE), the larger the firm size, the richer the information environment, the lesser the information asymmetry, and the higher the investment efficiency. The largest shareholder's ownership $(O W N)$ was shown to have a significant negative effect [53]. The higher the largest shareholder's ownership, the lower the investment efficiency. The foreign ownership rate is not statistically significant compared with investment efficiency, as shown in prior study [25].

Table 6 shows the results of Hypothesis 2, and indicates that analysts influence the relationship between SEO and investment efficiency. As a result of verifying the fit of the research model, the F value is significant at the $1 \%$ level, so the research model to verify the hypothesis is not problematic. In Table 6, the regression coefficient of SEODUM is multiplied by FOLLOW $\left(\beta_{3}\right)$, which indicates that the effect of analysts on the relationship between SEO and investment efficiency is 0.009 for the full sample, which is a significant positive value at the level of $5 \%$, and 0.011 for the underinvestment sample, which is a significant positive value at the $10 \%$ level, respectively.

In other words, the empirical results show that analyst coverage mitigates the negative relationship between SEO and investment efficiency. These results show that the greater the number of analysts, the greater the monitoring role, resulting in a decrease in earnings management, and hence an increase in investment efficiency. Additionally, the statistical significance is shown only in the total sample and the underinvestment sample, and it can be inferred that the relationship between SEO and investment 
efficiency is the result of the underinvestment sample. This implies that the funds raised by SEO are used for underinvestment, but investment efficiency is increased due to the monitoring effect of the analyst.

Table 5. The Effect of Seasoned Equity Offerings on Investment Efficiency.

\begin{tabular}{cccc}
\hline \multirow{2}{*}{ Variables } & Total Sample & Overinvestment Sample & Underinvestment Sample \\
\cline { 2 - 4 } & Coeff. $(t$-Value) & Coeff. $(t$-Value) & Coeff. $(t$-Value) \\
\hline INTERCEPT & $-1.054(-7.230)^{* * *}$ & $-1.112(-4.850)^{* * *}$ & $-1.052(-5.560)^{* * *}$ \\
SEODUM & $-0.045(-2.430)^{* *}$ & $-0.015(-0.540)$ & $-0.065(-2.620)^{* * *}$ \\
EQ & $0.285(2.400)^{* *}$ & $0.611(3.400)^{* * *}$ & $0.035(0.220)$ \\
SIZE & $0.009(1.640)^{*}$ & $0.011(1.270)$ & $0.009(1.290)$ \\
LEV & $0.048(1.560)$ & $0.067(1.470)$ & $0.020(0.480)$ \\
LOSSDUM & $0.011(0.660)$ & $0.025(1.020)$ & $-0.006(-0.290)$ \\
TA & $0.283(7.950)^{* * *}$ & $0.381(7.280)^{* * *}$ & $0.200(4.100)^{* * *}$ \\
STD_OCF & $-0.140(-1.580)$ & $-0.134(-0.970)$ & $-0.118(-1.030)$ \\
AGE & $-0.002(-0.270)$ & $0.003(0.200)$ & $-0.007(-0.670)$ \\
SLACK & $0.108(0.980)$ & $0.001(0.001)$ & $0.161(1.120)$ \\
OWN & $-0.082(-2.020)^{* * *}$ & $-0.038(-0.620)$ & $-0.108(-2.010)^{* *}$ \\
FOR & $-0.030(-0.570)$ & $-0.045(-0.540)$ & $-0.019(-0.290)$ \\
BIG4 & $-0.002(-0.160)$ & $0.013(0.600)$ & $-0.013(-0.690)$ \\
YD & Included & Included & Included \\
$I D$ & Included & Included & Included \\
F-VALUE & $32.88^{* * *}$ & $13.58 * * *$ & $21.85 * * *$ \\
ADJ $R$-SQ & $20.44^{* *}$ & $18.72 \%$ & $23.09 \%$ \\
\hline
\end{tabular}

Note: Please refer to Appendix A for variable definitions. ${ }^{* * *}, * *$, and ${ }^{*}$ denote significance at the $1 \%, 5 \%$, and $10 \%$ levels, respectively (two-tailed).

Table 6. The Effect of Analysts on the Relationship between Seasoned Equity Offerings and Investment Efficiency.

\begin{tabular}{|c|c|c|c|}
\hline \multirow{2}{*}{ Variables } & Total Sample & Overinvestment Sample & Underinvestment Sample \\
\hline & Coeff. ( $t$-Value) & Coeff. ( $t$-Value) & Coeff. ( $t$-Value) \\
\hline INTERCEPT & $-0.793(-2.530) * *$ & $-0.844(-1.700)$ * & $-0.682(-1.650) *$ \\
\hline SEODUM & $-0.103(-2.170) * *$ & $-0.086(-1.100)$ & $-0.128(-2.130)^{* *}$ \\
\hline FOLLOW & $-0.001(-0.560)$ & $-0.001(-0.220)$ & $-0.002(-0.630)$ \\
\hline SEODUM * FOLLOW & $0.009(2.160) * *$ & $0.008(1.170)$ & $0.011(1.910) *$ \\
\hline$E Q$ & $0.381(1.690)$ * & $0.769(2.200)^{* *}$ & $0.027(0.090)$ \\
\hline$S I Z Z$ & $0.001(0.070)$ * & $0.009(0.470)$ & $-0.005(-0.310)$ \\
\hline LEV & $0.033(0.570)$ & $0.018(0.200)$ & $0.026(0.330)$ \\
\hline LOSSDUM & $-0.002(-0.060)$ & $0.078(1.370)$ & $-0.076(-1.600)$ \\
\hline TA & $0.317(4.780) * * *$ & $0.438(4.480) * * *$ & $0.182(1.960)^{* *}$ \\
\hline STD_OCF & $-0.092(-0.570)$ & $-0.254(-0.980)$ & $0.039(0.180)$ \\
\hline$A \bar{G} E$ & $-0.005(-0.360)$ & $-0.010(-0.480)$ & $-0.004(-0.190)$ \\
\hline SLACK & $0.209(1.070)$ & $0.253(0.860)$ & $0.182(0.680)$ \\
\hline OWN & $-0.136(-1.730) * *$ & $-0.169(-1.380)$ & $-0.155(-1.470)$ \\
\hline FOR & $-0.003(-0.040)$ & $-0.044(-0.330)$ & $0.005(0.050)$ \\
\hline BIG4 & $0.023(0.760)$ & $-0.012(-0.270)$ & $0.045(1.100)$ \\
\hline$Y D$ & Included & Included & Included \\
\hline$I D$ & Included & Included & Included \\
\hline F-VALUE & $10.00^{* * *}$ & $4.48^{* * *}$ & $6.82^{* * *}$ \\
\hline$A D J R-S Q$ & $17.83 \%$ & $16.48 \%$ & $19.62 \%$ \\
\hline
\end{tabular}

Note: Please refer to Appendix A for variable definitions. ${ }^{* * *}, * *$, and ${ }^{*}$ denote significance at the $1 \%, 5 \%$, and $10 \%$ levels, respectively (two-tailed). 


\subsection{Additional Analysis}

The coverage of the analysts who follow a firm tends to be determined by the characteristics of the firm. In this section, Hypothesis 2 was re-verified by estimating unexpected analysts' coverage as a proxy for the analysts' coverage. Table 7 shows the results of Hypothesis 2, and indicates that unexpected analysts' coverage influence the relationship between SEO and investment efficiency. The variables for the coverage of analysts who are interested are based on $\mathrm{Yu}$ (2008)' [23] s methodology, which estimated the unexpected analysts' coverage, considering the original variables and the characteristics of firms providing forecast information. See Appendix B.2 for the definition of unexpected analysts' coverage.

The results of the analysis show that SEODUM $\times A b F O L L O W\left(\beta_{3}\right)$ is statistically significant and positive in the total sample and the underinvestment sample. The results of this analysis seem to support Hypothesis 2 firmly as a result of this analysis. This implies that analyst coverage has a moderating effect to mitigate the negative relationship between SEO and investment efficiency

Table 7. The Effect of Analysts on the Relationship between Seasoned Equity Offerings and Investment Efficiency.

\begin{tabular}{cccc}
\hline \multirow{2}{*}{ Variables } & Total Sample & Overinvestment Sample & Underinvestment Sample \\
\cline { 2 - 4 } & Coeff. $(\boldsymbol{t}$-Value) & Coeff. $(\boldsymbol{t}$-Value) & Coeff. $(\boldsymbol{t}$-Value) \\
\hline INTERCEPT & $-0.454(-1.430)$ & $-0.720(-1.450)$ & $-0.228(-0.540)$ \\
SEODUM & $-0.024(-0.680)$ & $-0.021(-0.370)$ & $-0.031(-0.670)$ \\
AbFOLLOW & $0.002(0.100)$ & $0.011(0.410)$ & $-0.004(-0.170)$ \\
SEODUM $\times$ AbFOLLOW & $0.054(1.830)$ & $0.011(0.190)$ & $0.072(1.800)^{*}$ \\
CONTROLS & Included & Included & Included \\
YD & Included & Included & Included \\
ID & Included & Included & $6.23 * * *$ \\
F-VALUE & $8.66^{* * *}$ & $3.73 * * *$ & $20.94 \%$ \\
ADJ $R$-SQ & $18.35 \%$ & $15.99 \%$ & . \\
\hline
\end{tabular}

Please refer to Appendix A for variable definitions. ${ }^{* * *}$ and ${ }^{*}$ denote significance at the $1 \%$ and $10 \%$ levels, respectively (two-tailed).

Table 8 shows the results of analyzing the effect of analysts on the relationship between SEO and investment efficiency by introducing FOLLOWDUM, which divided the total sample by the median of the analysts' coverage. Then, we further analyzed how the relationship between SEO and investment efficiency varied among groups according to analysts' coverage. As analysts' coverage increases, the role of monitoring improves. Therefore, if analysts' coverage is larger than the median, the negative impact between SEO and investment efficiency is expected to be further mitigated.

Panel A of Table 8 is the regression analysis of the total sample. As a result, the regression coefficient of SEODUM $\times$ FOLLOWDUM $\left(\beta_{3}\right)$ was 0.089 in the group where the analysts' coverage was larger than the median, and it was a significant positive value at the level of $5 \%$. This result shows that the group with more analyst coverage than the median has a better monitoring role, and the negative relationship between firms with SEO and investment efficiency appears to be mitigated. This is the result of firmly supporting the results of Hypothesis 2.

Panel B of Table 8 shows the results of a regression analysis for the overinvestment sample. As a result, the regression coefficient of SEODUM $\times$ FOLLOWDUM $\left(\beta_{3}\right)$ was a positive value $(0.084)$ in the group that had more analyst coverage than the median, but it was not statistically significant.

Panel $C$ of Table 8 shows the results of regression analysis for the underinvestment sample. As a result, the regression coefficient of SEODUM $\times$ FOLLOWDUM $\left(\beta_{3}\right)$ was 0.094 in the group with more than the median analyst coverage, which was a significant positive value at the level of $10 \%$.

This result shows that the group with more analyst coverage than the middle group had a better monitoring role, and that the negative relationship between firms with SEO and investment efficiency was mitigated in the group that had superior monitoring. In sum, the negative relationship 
between firms with SEO and investment efficiency is shown to be mitigated in the group with excellent monitoring, and this effect was significant only in the total group and the underinvestment sample group.

In addition to the results in Table 6, Hypothesis 2 was also supported when analysts' coverage was further analyzed as a dummy variable. The monitoring role of analysts has been firmly supported, and seems to be better performing in underinvestment samples than overinvestment samples.

Table 8. The Effect of Seasoned Equity Offerings on Investment Efficiency in the Information Environment: Analyst Followings.

\begin{tabular}{cccc}
\hline \multirow{2}{*}{ Variables } & Total Sample & Overinvestment Sample & Underinvestment Sample \\
\cline { 2 - 4 } & Coeff. $(t$-Value) & Coeff. $(t$-Value) & Coeff. $(t$-Value) \\
\hline INTERCEPT & $-0.986(-6.330)^{* * *}$ & $-1.028(-4.200)^{* * *}$ & $-1.008(-4.980)^{* * *}$ \\
SEODUM & $-0.058(-2.810)^{* * *}$ & $-0.022(-0.710)$ & $-0.084(-3.030)^{* * *}$ \\
FOLLOWDUM & $0.001(0.030)$ & $-0.004(-0.120)$ & $0.002(0.080)$ \\
SEODUM $\times$ FOLLOWDUM & $0.089(1.960)^{* *}$ & $0.084(1.190)$ & $0.094(1.890)^{*}$ \\
CONTROLS & Included & Included & Included \\
YD & Included & Included & Included \\
ID & Included & Included & Included \\
F-VALUE & $30.77^{* * *}$ & $12.39 * * *$ & $20.86^{* * *}$ \\
ADJ $R$-SQ & $21.14 \%$ & $17.98 \%$ & $23.13 \%$ \\
\hline
\end{tabular}

Note: Please refer to Appendix A for variable definitions. ${ }^{* * *}, * *$, and ${ }^{*}$ denote significance at the $1 \%, 5 \%$, and $10 \%$ levels, respectively (two-tailed).

The most significant changes after the adoption of K-IFRS are the principle-based standard framework, the introduction of basic financial statements in consolidated financial statements, and the expansion of fair value assessments. These changes in the accounting environment will lead to changes in the information environment of the analysts.

The expansion of managerial discretion due to the basic financial statements and principle-based standard framework of consolidated financial statements is a burden for analysts to interpret additional information. However, due to the principle-based standard system and the expansion of fair value evaluation, it is anticipated that the increase in notes disclosure will provide additional information to analysts, which will serve as an advantage for obtaining information [22,54].

In this section, we predict that there will be a change in the earnings quality and information environment for firms and the information environment for analysts after the adoption of K-IFRS (Korean International Financial Reporting Standards). As a result, Hypothesis 1 and Hypothesis 2 were further divided into periods before and after the adoption of K-IFRS. The additional analysis results of Hypothesis 1 are as follows.

Panel A of Table 9 shows the regression analysis of total sample. As a result of the analysis, the regression coefficient of SEODUM $\left(\beta_{1}\right)$ was -0.051 in the group before K-IFRS adoption, which was a significant negative value at the level of $5 \%$. On the other hand, the regression coefficient of SEODUM $\left(\beta_{1}\right)$ was -0.024 in the group after K-IFRS adoption, which was not a significant negative value.

Panel B of Table 9 is the regression analysis of the overinvestment sample. The regression coefficient of SEODUM $\left(\beta_{1}\right)$ was -0.034 in the group before K-IFRS adoption, which was not a significant negative value. On the other hand, the regression coefficient of SEODUM $\left(\beta_{1}\right)$ was 0.050 in the group after K-IFRS adoption, which was not a significant positive value.

Panel $C$ of Table 9 is the regression analysis of the underinvestment sample. The regression coefficient of SEODUM $\left(\beta_{1}\right)$ was -0.069 in the group before K-IFRS adoption, which was a significant negative value at the level of $5 \%$. On the other hand, the regression coefficient of SEODUM $\left(\beta_{1}\right)$ was -0.066 in the group after K-IFRS adoption, which was a significant negative value at the level of $10 \%$.

The relationship between SEO and investment efficiency is similar to that of this study before the adoption of K-IFRS, but after the introduction of K-IFRS, the negative relationship was not statistically significant. The results of this additional analysis show that after the adoption of K-IFRS, there is no 
statistically significant or negative relationship between SEO and investment efficiency, indicating that the information environment has indirectly improved after the adoption of K-IFRS.

Table 9. The Effect of Seasoned Equity Offerings on Investment Efficiency: Pre-K-IFRS vs. Post-K-IFRS.

\begin{tabular}{|c|c|c|c|c|}
\hline \multirow{3}{*}{$\begin{array}{l}\text { PANEL A } \\
\text { Variables }\end{array}$} & \multicolumn{4}{|c|}{ Total Sample } \\
\hline & \multicolumn{2}{|c|}{ Pre-IFRS } & \multicolumn{2}{|c|}{ Post-IFRS } \\
\hline & Coeff. & $t$-Value & Coeff. & $t$-Value \\
\hline INTERCEPT & -1.064 & $-5.700 * * *$ & -1.060 & $-4.590^{* * *}$ \\
\hline SEODUM & -0.051 & $-2.090 * *$ & -0.024 & -0.860 \\
\hline CONTROLS & \multicolumn{2}{|c|}{ Included } & \multicolumn{2}{|c|}{ Included } \\
\hline$Y D$ & \multicolumn{2}{|c|}{ Included } & \multicolumn{2}{|c|}{ Included } \\
\hline$I D$ & \multicolumn{2}{|c|}{ Included } & \multicolumn{2}{|c|}{ Included } \\
\hline$F-V A L U E$ & \multicolumn{2}{|c|}{$20.53^{* * *}$} & \multicolumn{2}{|c|}{$23.21^{* * *}$} \\
\hline$A D J R-S Q$ & \multicolumn{2}{|c|}{$17.90 \%$} & \multicolumn{2}{|c|}{$25.66 \%$} \\
\hline PANEL B & \multicolumn{4}{|c|}{ Overinvestment Sample } \\
\hline \multirow{2}{*}{ Variables } & \multicolumn{2}{|c|}{ Pre-IFRS } & \multicolumn{2}{|c|}{ Post-IFRS } \\
\hline & Coeff. & $t$-Value & Coeff. & $t$-Value \\
\hline INTERCEPT & -1.004 & $-3.420 * * *$ & -1.340 & $-3.580^{* * *}$ \\
\hline SEODUM & -0.034 & -0.930 & 0.050 & 1.140 \\
\hline CONTROLS & \multicolumn{2}{|c|}{ Included } & \multicolumn{2}{|c|}{ Included } \\
\hline$Y D$ & \multicolumn{2}{|c|}{ Included } & \multicolumn{2}{|c|}{ Included } \\
\hline$I D$ & \multicolumn{2}{|c|}{ Included } & \multicolumn{2}{|c|}{ Included } \\
\hline F-VALUE & \multicolumn{2}{|c|}{$8.47^{* * *}$} & \multicolumn{2}{|c|}{$8.29 * * *$} \\
\hline$A D J R-S Q$ & \multicolumn{2}{|c|}{$15.75 \%$} & \multicolumn{2}{|c|}{$22.70 \%$} \\
\hline PANEL C & \multicolumn{4}{|c|}{ Underinvestment Sample } \\
\hline \multirow{2}{*}{ Variables } & \multicolumn{2}{|c|}{ Pre-IFRS } & \multicolumn{2}{|c|}{ Post-IFRS } \\
\hline & Coeff. & $t$-Value & Coeff. & $t$-Value \\
\hline INTERCEPT & -1.114 & $-4.540 * * *$ & -0.974 & $-3.340^{* * *}$ \\
\hline SEODUM & -0.069 & $-2.070 * *$ & -0.066 & 1.860 * \\
\hline CONTROLS & & luded & & luded \\
\hline$Y D$ & & luded & & luded \\
\hline$I D$ & & luded & & luded \\
\hline F-VALUE & & $53 * * *$ & & $75 * * *$ \\
\hline$A D J R-S Q$ & & $17 \%$ & & $.00 \%$ \\
\hline
\end{tabular}

Note: Please refer to Appendix A for variable definitions. ${ }^{* * *}, * *$, and ${ }^{*}$ denote significance at the $1 \%, 5 \%$, and $10 \%$ levels, respectively (two-tailed).

The additional analysis result of Hypothesis 2 is as follows. Panel A of Table 10 is the regression analysis of the total sample. As a result, the regression coefficient of $S E O D U M \times A b F O L L O W\left(\beta_{3}\right)$ was 0.084 in the group before the adoption of K-IFRS, which was a significant positive value at the level of $10 \%$. On the other hand, the regression coefficient of SEODUM $\times A b F O L L O W\left(\beta_{3}\right)$ was 0.211 in the group after K-IFRS adoption, which was a significant positive value at the level of $5 \%$.

We find that the regression coefficients and significance increased in groups after K-IFRS adoption compared with those before K-IFRS adoption. This implies that the financial environment has improved since the adoption of K-IFRS, information asymmetry has decreased due to an increase in earnings quality, and the analysis environment for analysts has improved due to the provision of additional information.

Panel B of Table 10 is the regression analysis of the overinvestment sample. As a result, the regression coefficient of SEODUM $\times A b F O L L O W\left(\beta_{3}\right)$ was 0.069 in the group before the adoption of K-IFRS, which was not a significant positive value. On the other hand, the regression coefficient of SEODUM $\times A b F O L L O W\left(\beta_{3}\right)$ was 0.299 in the group after K-IFRS adoption, which was a significant positive value at the level of $10 \%$. 
Table 10. The Effect of Analysts on the Relationship between Seasoned Equity Offerings and Investment Efficiency: Pre-K-IFRS vs. Post-K-IFRS.

\begin{tabular}{|c|c|c|c|c|}
\hline PANEL A & \multicolumn{4}{|c|}{ Total Sample } \\
\hline \multirow{2}{*}{ Variables } & \multicolumn{2}{|c|}{ Pre-IFRS } & \multicolumn{2}{|c|}{ Post-IFRS } \\
\hline & Coeff. & $t$-Value & Coeff. & $t$-Value \\
\hline INTERCEPT & -0.335 & -0.910 & -0.699 & -1.150 \\
\hline SEODUM & -0.061 & -1.380 & 0.126 & 1.530 \\
\hline AbFOLLOW & 0.026 & 1.230 & -0.065 & $-2.210^{* *}$ \\
\hline$S E O D U M \times A b F O L L O W$ & 0.084 & $1.860 *$ & 0.211 & $2.660 * *$ \\
\hline CONTROLS & \multicolumn{2}{|c|}{ Included } & \multicolumn{2}{|c|}{ Included } \\
\hline$Y D$ & \multicolumn{2}{|c|}{ Included } & \multicolumn{2}{|c|}{ Included } \\
\hline$I D$ & \multicolumn{2}{|c|}{ Included } & \multicolumn{2}{|c|}{ Included } \\
\hline F-VALUE & \multicolumn{2}{|c|}{$6.24 * * *$} & \multicolumn{2}{|c|}{$6.77^{* * *}$} \\
\hline$A D J R-S Q$ & \multicolumn{2}{|c|}{$15.18 \%$} & \multicolumn{2}{|c|}{$36.58 \%$} \\
\hline PANEL B & \multicolumn{4}{|c|}{ Overinvestment Sample } \\
\hline \multirow{2}{*}{ Variables } & \multicolumn{2}{|c|}{ Pre-IFRS } & \multicolumn{2}{|c|}{ Post-IFRS } \\
\hline & Coeff. & $t$-Value & Coeff. & $t$-Value \\
\hline INTERCEPT & -0.690 & -1.230 & -1.350 & -1.410 \\
\hline SEODUM & -0.060 & -0.850 & 0.163 & 1.040 \\
\hline AbFOLLOW & 0.008 & 0.240 & -0.038 & -0.760 \\
\hline$S E O D U M \times A b F O L L O W$ & 0.069 & 0.990 & 0.299 & 1.800 * \\
\hline CONTROLS & \multicolumn{2}{|c|}{ Included } & \multicolumn{2}{|c|}{ Included } \\
\hline$Y D$ & \multicolumn{2}{|c|}{ Included } & \multicolumn{2}{|c|}{ Included } \\
\hline$I D$ & \multicolumn{2}{|c|}{ Included } & \multicolumn{2}{|c|}{ Included } \\
\hline$F-V A L U E$ & \multicolumn{2}{|c|}{$8.47^{* * *}$} & \multicolumn{2}{|c|}{$8.29 * * *$} \\
\hline$A D J R-S Q$ & \multicolumn{2}{|c|}{$15.75 \%$} & \multicolumn{2}{|c|}{$22.70 \%$} \\
\hline PANEL C & \multicolumn{4}{|c|}{ Underinvestment Sample } \\
\hline Variables & & IFRS & & -IFRS \\
\hline & Coeff. & $t$-Value & Coeff. & $t$-Value \\
\hline INTERCEPT & -0.154 & -0.310 & -0.446 & -0.550 \\
\hline SEODUM & -0.061 & -1.060 & 0.140 & 1.370 \\
\hline AbFOLLOW & 0.037 & -1.320 & -0.108 & $-2.810^{* * *}$ \\
\hline$S E O D U M \times A b F O L L O W$ & 0.094 & 1.570 & 0.212 & $2.170 * *$ \\
\hline CONTROLS & & uded & & uded \\
\hline$Y D$ & & uded & & uded \\
\hline$I D$ & & uded & & uded \\
\hline F-VALUE & & 1 1** & & $75 * * *$ \\
\hline$A D J R-S Q$ & & $20 \%$ & & $.00 \%$ \\
\hline
\end{tabular}

Note: Please refer to Appendix A for variable definitions. ${ }^{* * *}, * *$, and * denote significance at the $1 \%, 5 \%$, and $10 \%$ levels, respectively (two-tailed).

Since the adoption of K-IFRS shows statistical significance in the overinvestment sample, the monitoring role of the analyst, which was limited in the overinvestment sample, seems to be strengthened by the improvement of the analytical environment of the analyst and the accounting environment after K-IFRS adoption.

Panel $\mathrm{C}$ of Table 10 is the regression analysis of the underinvestment sample. As a result, the regression coefficient of SEODUM $\times$ AbFOLLOW $\left(\beta_{3}\right)$ was 0.094 in the group before the adoption of K-IFRS, which was not a significant positive value. On the other hand, the regression coefficient of SEODUM $\times A b F O L L O W\left(\beta_{3}\right)$ was 0.212 in the group after K-IFRS adoption, which was a significant positive value at the level of $5 \%$.

The results of this study suggest that the monitoring role of analysts after the adoption of K-IFRS was better performed in the underinvestment sample than in the overinvestment sample, as the statistical significance of the underinvestment sample was more robust than that of the overinvestment sample. In sum, the effect of analysts on the relationship between SEO and investment efficiency increases after the adoption of K-IFRS compared with before K-IFRS adoption. This additional analysis 
suggests indirectly that analysts are performing better in the monitoring role after the adoption of K-IFRS.

\section{Conclusions}

This study analyzed the effects of SEO on investment efficiency using a sample of 5297 firms from 2002 to 2014. In addition, we examined whether the monitoring role of analysts affects the relationship between SEO and investment efficiency. The investment efficiency measurement method was devised by McNichols and Stubben (2008) [21]. SEO results in a substantial increase in the net assets of a firm with the increase of stocks by issuing stocks. SEO is the most basic way to improve the financial structure of a firm and get rid of debt financing, because it is a method of expanding equity capital by issuing shares.

Managers are incentivized to raise the issue price of stocks rather than the intrinsic value of the firm in the process of SEO. Many prior studies have reported that earnings are managed through accruals and real activities during SEO. As such, managers' voluntary earnings management may damage the quality of financial reporting.

In addition, investment efficiency refers to the adoption of investment plans with positive NPV under circumstances where there is no market friction such as adverse selection or agency costs [19,27]. However, due to realistic constraints, optimal investment is often not achieved. In other words, as an agent problem due to information asymmetry, optimal investment is not made, resulting in underinvestment or overinvestment [33].

Many prior studies on investment efficiency have addressed its relationship with the quality of financial reporting, finding that the better the quality of the financial reporting, the more efficient the investment. The purpose of this study is to investigate the relationship between SEO and investment efficiency by focusing on the prior study that the arbitrary earnings management of the manager in the case of SEO damages the quality of the financial report. In addition, we examined the effect of analysts on the relationship between SEO and investment efficiency.

Analysts perform a monitoring role in firms' financial reporting processes $[23,25,43,44]$. In fact, $\mathrm{Yu}$ (2008) [23] and Yoo et al. (2012) [44] confirmed that the discretionary accruals decrease more in firms with many analysts. Yoo et al. (2012) confirmed that as the number of analysts increases, earnings management through real activities decreases. Thus, if analysts monitor the managers' behavior in the financial reporting process, the relationship between SEO and investment efficiency is expected to be mitigated.

The results of this study are as follows. A firm with a SEO has lower investment efficiency than a firm without a SEO. As a result, the statistical significance was found only in the full sample and the underinvestment sample.

This is consistent with the prior study in which firms with SEO are subject to opportunistic earnings management $[4-6,8,9]$. Second, the effect of analyst coverage on the relationship between capital increase and investment efficiency is significant in terms of investment efficiency, and there the interaction between SEO and analyst coverage has a positive direction. The results of this analysis show that analysts play a role in monitoring the inefficient investments derived from managers' opportunistic earnings management. In other words, it suggests that analyst coverage is acting as a mechanism to mitigate the negative relationship between SEO and investment efficiency.

In addition, we conducted a further analysis on abnormal analyst coverage, including examining groups of analysts before and after introducing K-IFRS. First, we used the original variables for analyst coverage as variables. However, analyst coverage is often determined by the characteristics of the firm. To compensate, we estimated the amount of abnormal analysts that exclude the characteristics of the firm and used them as a proxy for analyst coverage. As a result of the analysis, the analytical results were maintained even when the abnormal analysts were used. Second, analyst coverage was used as a substitute for the monitoring role. Analyst coverage was classified by the median. The group that was larger than the median was classified into the group with superior monitoring, and the group 
that was smaller than the median was classified into the group with less effective monitoring. As a result of the analysis, it was found that the group that was larger than the median performed the monitoring role better than the group that was smaller than the median. Third, the adoption of K-IFRS obligations brought about many changes in the accounting reporting environment and the analysis environment of analysts. Accordingly, the analysis before and after the introduction of K-IFRS was analyzed separately. The analyst monitoring effect was greater after the introduction of K-IFRS than before the introduction of K-IFRS. This indirectly shows that the adoption of K-IFRS has improved the accounting reporting environment and the analyst's financial statement analysis environment.

The contribution of this study is as follows. First, the prior study examined financing from the perspective that earnings management through accruals and real activities are performed in the case of SEO. On the other hand, it is significant that this study deals with the capital management aspect of investment efficiency after financing. Second, it is significant that the poor performance after SEO can be attributed not only to the management of discretionary accruals and management based on real activities, but also to inefficient investment activities. Third, we examined the effects of the choice of accounting for a firm in terms of financing and capital management. Fourth, we showed that analysts can play a role in monitoring the quality of financial reporting by showing that analysts can influence the relationship between SEO and investment efficiency. The results show that the efficient operation of the capital procured is important for the sustainability of the firm and that the analyst plays an important role in monitoring the efficient allocation of resources as an external auditor.

As for the limitations of this study, variables may have been omitted that affect investment efficiency. Also, there may be measurement errors in determining investment efficiency and abnormal analyst coverage. Research on the effect of the financing type of SEO and the purpose of SEO on investment efficiency will be needed in the future. Also, research that reflects industry characteristics will also be germane to the topic.

Author Contributions: H.M.O. conceived and designed the paper, performed the literature review and the data analysis, and wrote the paper. W.Y.K. reviewed the entire process, performed the literature review, and wrote the paper.

Funding: This research received no external funding.

Conflicts of Interest: The authors declare no conflict of interest.

\section{Appendix A. Variable Definitions for $\mathrm{H}_{1}, \mathrm{H}_{2}$}

Dependent Variables: INV_EF = investment efficiency, the absolute value of the residual measured as McNichols and Stubben (2008) [21] multiplied by (-1) for firm i in year $t+1$.

Explanatory Variables: SEODUM = seasosed equity offerings dummy variable, 1 if the firm with seasosed equity offerings, and 0 otherwise for firm i in year $t-1$; SEODUM $\times F O L L O W=$ Interaction variables between SEODUM and FOLLOW

\section{Control Variables}

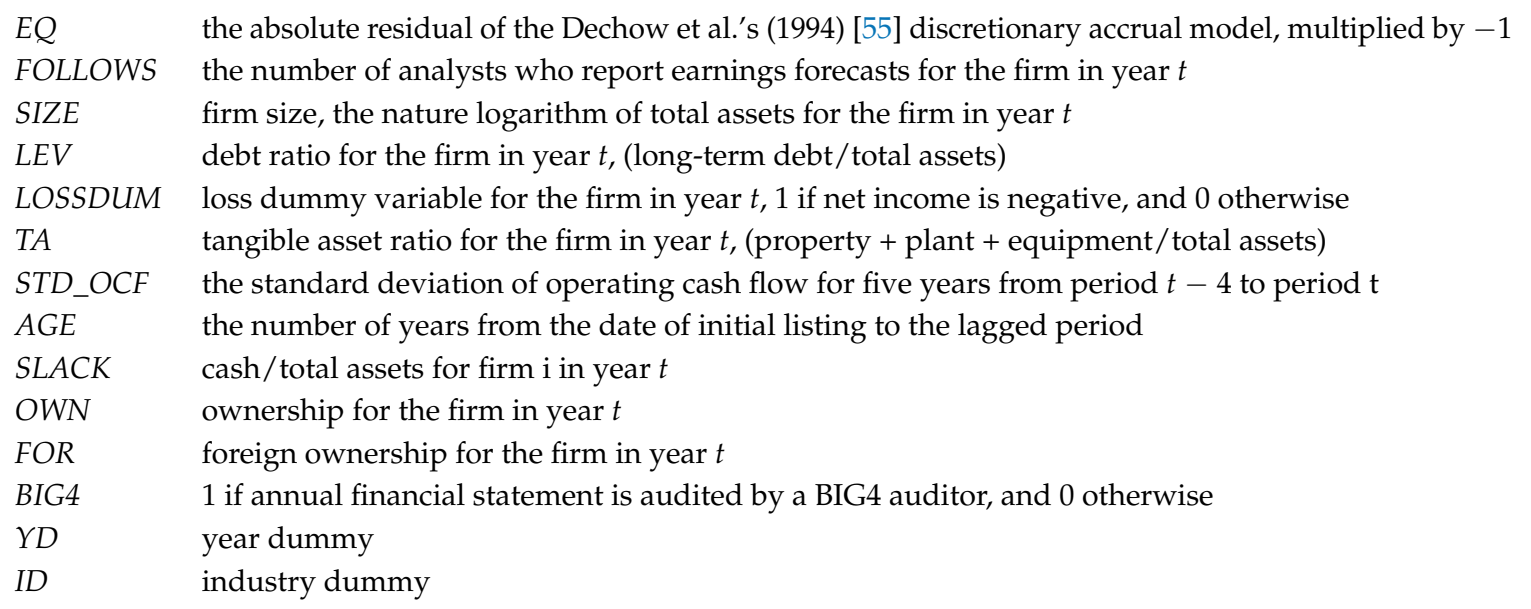




\section{Appendix B}

Appendix B.1. Investment Efficiency is Measured as McNichols and Stubben (2008)

In this study, we used the method of McNichols and Stubben (2008) [21] as a proxy for investment efficiency. In the model estimated by the following equation, the residual means investment inefficiency. Over-investment sample if the residual is greater than 0 and under-investment sample if the residual is less than zero.

$$
\begin{aligned}
\text { INVEST }_{i t}=\beta_{0} & +\beta_{1} Q_{i t-1}+\beta_{2} Q_{i t-1} * \text { Quartile }_{i t-1}+\beta_{3} Q_{i t-1} * \text { Quartile }_{i t-1} \\
& +\beta_{4} Q_{i t-1} * \text { Quartile }_{i t-1}+\beta_{5} C F_{i t}+\beta_{6} \text { GROWTH }_{i t} \\
& +\beta_{7} \text { INVEST }_{i t-1}+\varepsilon_{i t}
\end{aligned}
$$

where INVEST $T_{i t}$ is capital investment for firm in year $t$; $Q_{i t-1}$ is Tobin's $Q$ for firm in year $t-1$; $Q_{i t-1} *$ Quartile $2(3,4)_{i t-1}$ is Tobin's $Q$ for firm in year $t-1 *$ dummy variable with a value of 1 if Tobin's $Q$ belongs to the second (third, fourth) quartile by year-industy; $C F_{i t}$ is operating cash flow for $\mathrm{t} /$ tangible assets for firm in year $t-1 ; G R O W T H_{i t-1}$ is growth ratio for firm in year $t-1$, (total assets for firm in year $t-1$ minus total assets for firm in year $t-2$ ) divided by total assets for firm in year $t-2 ; I^{\prime N V E S T} T_{i t-1}$ is capital investment for firm in year $t-1 ; \varepsilon_{i t}$ is residual.

\section{Appendix B.2. Unexpected Analyst Coverage is Measured as Yu (2008)}

The method of $\mathrm{Yu}$ (2008) [23] was applied to measure the unexpcted analysts coverage. The estimation formula is as follows. The residual estimated by the regression equation below is the unexpcted analysts coverage. If the residual is larger than 0 , it means that the number of analysts is larger than the expected number of analysts. If the residual is smaller than 0 , it means that the number of analysts is smaller than the expected analysts. The greater the number of unexpcted analysts, the greater the monitoring role is expected.

$$
\text { FOLLOW }_{i t}=\beta_{0}+\beta_{1} S I Z E_{i t}+\beta_{2} R O A_{i t}+\beta_{3} G R W_{i t}+\beta_{4} S T D \_O C F_{i t}+\beta_{5} \text { FINAN }_{i t}+\varepsilon_{i t}
$$

where FOLLOW is the number of analysts who report earnings forecasts for the firm in year $t$; SIZE is firm size, the nature logarithm of total assets for the firm in year $t$; $R O A$ is profitability, net income is divided by total assets; GRW is growth rate, (total assets for firm in year $\mathrm{t}$ minus total assets for firm in year $t-1$ ) divided by total assets for firm in year $t-1$; STD_OCF is standard deviation of operating cash flows over the past five years; FINAN is (debt financing + equity financing) divided by total assets for firm in year $t ; \varepsilon_{i t}$ is residual.

\section{References}

1. Jang, J.Y.; Lee, H.J.; Hwang, S.H. The effects of seasoned equity offering methods on firm characteristics and stock market reactions: Shareholder priority public offering and Allotment to the third party. Korea Bus. Educ. Res. 2010, 59, 83-105. (In Korean)

2. Kim, Y.T.; Hwang, S.H. Earnings management of a types of seasoned equity offering in Korea firms. Acc. Inf. Res. 2009, 27, 1-31. (In Korean)

3. Kim, J.W. Earning Management Using Accruals and the long-run performance of SEOs. Korean Bus. Res. 2013, 28, 165-191. (In Korean)

4. Choi, K.; Paek, W.S. An Empirical study on earnings management of firms with seasoned equity offerings. Korean Account. Rev. 1999, 24, 1-28. (In Korean)

5. Rangan, S. Earnings management and the performance of Seasoned Equity Offerings. J. Financ. Econ. 1998, 50, 101-122. [CrossRef]

6. Teoh, S.; Welch, I.; Wong, T. Earnings management and the long-run underperformance of Seasoned Equity Offerings. J. Financ. Econ. 1998, 50, 63-100. [CrossRef] 
7. Yoon, S.S.; Lee, G.Y. Seasoned Equity Offerings and earnings management. Korean Account. Rev. 2001, 26, 1-26. (In Korean)

8. Cohen, D.; Zarowin, P. Accrual-based and real earnings management activities around seasoned equity offerings. J. Account. Econ. 2010, 50, 2-19. [CrossRef]

9. Kang, S.A.; Jeon, S.B. Consequences of real activity based earnings management: Evidence of seasoned equity offering firms in Korea. Korean Manag. Rev. 2010, 39, 595-632. (In Korean)

10. Francis, J.; LaFond, R.; Olsson, P.M.; Schipper, K. Cost of equity and earnings attributes. Account. Rev. 2004, 79, 967-1010. [CrossRef]

11. Francis, J.; LaFond, R.; Olsson, P.M.; Schipper, K. The market pricing of accruals quality. J. Account. Econ. 2005, 39, 295-327. [CrossRef]

12. Bharath, S.T.; Sunder, J.; Sunder, S.V. Accounting quality and debt contracting. Account. Rev. 2008, 83, 1-28. [CrossRef]

13. Hong, S.W.; Yi, H.D. The relationship among seasoned equity offerings, bond Issues, capital structures, and earnings management. Korean Account. Rev. 2016, 41, 1-30. (In Korean)

14. Ban, H.J. Accounting quality and investment efficiency by corporate governance structures. Korean J. Bus. Adm. 2011, 24, 3079-3096. (In Korean)

15. Bushman, R.; Smith, A. Financial accounting information and corporate governance. J. Account. Econ. 2001, 32, 237-333. [CrossRef]

16. Ashbaugh, H.; Collins, D.; LeFond, R. The effects of corporate governance on firms' credit ratings. J. Account. Econ. 2006, 42, 203-243. [CrossRef]

17. Son, P.D. The relationship between Earnings quality and future capital investment and efficiency. Korean Ind. Econ. Res. 2013, 26, 315-332. (In Korean)

18. Biddle, G.; Hilary, G. Accounting quality and firm-level capital investment. Account. Rev. 2006, 81, $963-982$. [CrossRef]

19. Biddle, G.; Hilary, G.; Verdi, R.S. How does financial reporting quality relate to investments efficiency? J. Account. Econ. 2009, 48, 112-131. [CrossRef]

20. Chen, F.; Hope, O.K.; Li, Q.; Wang, X. Financial reporting quality and investment efficiency of private firms in emerging markets. Account. Rev. 2011, 86, 1255-1288. [CrossRef]

21. McNichols, M.F.; Stubben, S.R. Does earnings management affect firms' investment decisions? Account. Rev. 2008, 83, 1571-1603. [CrossRef]

22. Oh, H.M.; Park, S.B.; Chun, H.J. The effect of K-IFRS adoption on the relationship between analyst coverage and conservatism. Study Account. Tax. Audit. 2018, 60, 171-216. (In Korean)

23. Yu, F. Analyst coverage and earnings management. J. Financ. Econ. 2008, 88, 245-271. [CrossRef]

24. Knyazeva, D. Corporate Governance, Analyst Following, and Firm Behaviour; Working Paper; New York University: New York, NY, USA, 2007.

25. Choi, S.U.; Lee, W.J. Analyst coverage and corporate investment efficiency. J. Ind. Econ. Bus. 2015, 28, 317-336. (In Korean)

26. Shivakumar, L. Do firms mislead investors by overstating earnings before seasoned equity offerings? J. Account. Econ. 2000, 29, 339-371. [CrossRef]

27. Lee, B.M.; Paek, W.S. Investment efficiency, earnings persistence, and value relevance. Korean Manag. Rev. 2015, 44, 1277-1304. [CrossRef]

28. Abel, A. Optimal investment under uncertainty. Am. Econ. Rev. 1983, 73, 228-233.

29. Hayashi, F. Tobin's marginal q and average q: A neoclassical interpretation. Econometrica 1982, 50, $213-224$. [CrossRef]

30. Yoshikawa, H. On the 'q' theory of investment. Am. Econ. Rev. 1980, 70, 739-743.

31. Crotty, J.R. Neoclassical and Keynesian approaches to the theory of investment. J. Post Keynes. Econ. 1992, 14, 483-496. [CrossRef]

32. Gordon, M.J. The Neoclassical and a post Keynesian theory of investment. J. Post Keynes. Econ. 1992, 14, 425-443. [CrossRef]

33. Myers, S.C. Determinants of corporate borrowing. J. Financ. Econ. 1977, 5, 147-175. [CrossRef]

34. Bertrand, M.; Mullainathan, S. Enjoying the quiet life? Corporate governance and managerial preference. J. Political Econ. 2003, 111, 1043-1075. [CrossRef]

35. Hubbard, R.G. Capital-market imperfections and investment. J. Econ. Lit. 1998, 36, 193-225. [CrossRef] 
36. Jensen, M.; Meckling, W. Theory of the firm: Management behavior, agency costs, and ownership structure. J. Financ. Econ. 1976, 3, 305-360. [CrossRef]

37. Myers, S.C.; Majluf, N.S. Corporate financing and investment decisions when firms have information that investors do not have. J. Financ. Econ. 1984, 13, 187-221. [CrossRef]

38. Hope, O.; Thomas, W.B. Managerial empire building and firm disclosure. J. Account. Res. 2008, 46, 591-626. [CrossRef]

39. Lambert, R.; Leuz, C.; Verrecchia, R. Accounting information, disclosure, and the cost of capital. J. Account. Res. 2007, 45, 385-420. [CrossRef]

40. Stiglitz, J.; Weiss, A. Credit rationing in markets with imperfect information. Am. Econ. Rev. 1981, 71, 393-410. [CrossRef]

41. Garcia Lara, J.M.; Osma, B.G.; Penalva, F. Accounting conservatism and corporate governance. Rev. Account. Stud. 2009, 14, 161-201. [CrossRef]

42. Choi, H.S.; Kim, C.B. The Effects of Earnings Quality on the association between external costs of capital and investments. Acc. Inf. Res. 2012, 30, 261-283. (In Korean)

43. Dyck, A.; Morse, A.; Zingales, L. Who blows the whistle on corporate fraud? J. Financ. 2010, 65, $2213-2253$. [CrossRef]

44. Yoo, J.M.; Yoon, K.S.; Goh, J.M.; Kim, D.H. Effects of analysts coverage on accrual-based and real earnings management: A comparison of Korea and the US. Korean Account. J. 2012, 21, 175-207. (In Korean)

45. Doukas, J.A.; Kim, C.; Pantzalis, C. Do analysts influence corporate financing and investment? Financ. Manag. 2008, 37, 303-339. [CrossRef]

46. Goh, J.M.; Cho, J.E.; Kim, D.H. Effects of analysts following on quality of timely disclosure. Korean J. Account. Res. 2012, 17, 399-430. (In Korean)

47. Lee, S.Y. A study on the change in value-relevance of accounting information before and after 1997 financial crisis. J. Tax. Account. 2009, 10, 35-75. (In Korean)

48. Healy, P.M.; Palepu, K.G. Information asymmetry, corporate disclosure, and the capital markets: A review of the empirical disclosure literature. J. Account. Econ. 2001, 31, 405-440. [CrossRef]

49. Sun, J. Governance role of analyst coverage and investor protection. Financ. Anal. J. 2009, 65, 52-64. [CrossRef]

50. Sun, J.; Liu, G. Industry specialist auditors, outside directors, and financial analysts. J. Account. Public Policy 2011, 30, 367-382. [CrossRef]

51. Lee, J.H.; Koh, Y.S. The effect of related party transaction on long term performance of SEOs. Korean Manag. Rev. 2016, 45, 403-432. [CrossRef]

52. Cho, S.M.; Kang, S.A. The effect of industry competition intensity on capital investment efficiency. Korea Bus. Educ. Res. 2016, 31, 23-43. [CrossRef]

53. Kim, Y.C.; Byun, Y.J. The effect of ownership structure on the relationship between stock option exercises and earnings management. Account. Inf. Res. 2010, 28, 101-129. (In Korean)

54. Nam, H.J. K-IFRS Adoption and financial analyst's forecasts. Korean Manag. Rev. 2015, 44, 933-956. [CrossRef]

55. Dechow, P.M. Accounting earnings and cash flows as measures of firm performance: The role of accounting accruals. J. Account. Econ. 1994, 18, 3-42. [CrossRef]

(C) 2018 by the authors. Licensee MDPI, Basel, Switzerland. This article is an open access article distributed under the terms and conditions of the Creative Commons Attribution (CC BY) license (http://creativecommons.org/licenses/by/4.0/). 